\title{
Abstract Nature of Money and the Modern Equation of Exchange
}

\author{
Mieczysław Dobija \\ Department of Management, Cracow University of Economics, Cracow, Poland \\ E-mail:dobijam@uek.krakow.pl \\ Received February 11, 2011; revised February 28, 2011; accepted March 25, 2011
}

\begin{abstract}
The essence of money economy reveals an abstract triad: capital-labor-money, where capital is an ability of doing work, labor is a transfer of the capital to products, and wages receivables correctly define money earned by the employees. The only proper money creating process is through labor. Money is a certification of work done; therefore labor is always self-financing. Using this theoretical framework, Governments can eliminate budget deficit, reduce direct taxes and unemployment while avoiding inflation. If the compensation paid in the public sector comes from the funds collected by taxation the economy works as a scarcity machine. In the reshaped economic system the Central Bank directly transfers salaries earned by the public sector employees to their bank accounts. Then the budgets are balanced, the direct taxes are limited, and the public debt no longer grows. The modern equation of exchange involves labor productivity as a fundamental economic ratio.
\end{abstract}

Keywords: Capital, Labor, Money, Central Banking, Labor Productivity, Equation of Exchange, Budget Deficit

\section{Introduction}

The recent comprehension of capital and its nature opens up a new way to perceive economic matters. Capital, the most important economic category, which has been studied for decades [1-3] has at last been described as the abstract capability of doing labor. It is worth noting that in order for an object to have the ability to work, it has to have the ability to exist. This short definition requires extensive explanations that have been given by the author of this paper [4] and others. In relation to the prophetic Ch. Bliss' opinion [1] “( $\ldots)$ When economists reach agreement on the theory of capital they will shortly reach agreement on everything (...)" it is simply the understanding of labor as the transfer of capital to products. Then the last question arises about the perception of money. Money is the third part of the triad capital-labor-money and it correctly arises as confirmation of labor done; that is to say, the work receivables. The above triad is absolutely abstract and each deviation leads to error. Therefore, money cannot be seen as coins or other material artifacts.

The model of capital explains its dynamic nature and it is deeply set in the fundamental laws of reality, those $P$.
Atkins [5] recognized as "driving the Universe." The model of capital $C_{t}$ is as follows:

$$
C_{t}=C_{0} e^{p t} e^{-s t} e^{m t}, p=E(s)=0.08[1 / \text { year }]
$$

Here $t$-is the coordinating (calendar) time measured by chosen cyclical movements, particularly of the Earth. The factor $e^{p t}$ is the factor of natural potential growth of capital determined by the constant of potential growth $p$ $=0.08$. The factor $e^{-s t}$ is the thermodynamic arrow of time; where $s$ is the rate of spontaneous random diffusion of the initial capital $C_{0}$. The factor $e^{m t}$ is an influence of human labor and management, which can offset to some extent the natural diffusion of capital s. In addition, labor changes potential to real growth.

The discovery of the constant of potential growth reminds us of the Physiocrats idea. The truth is that by labor $(m)$ the dispersion $(-s)$ is diminished so that the $(p)$ becomes a source of income. Much estimation was made in many economic fields to establish the value of the constant. It was estimated on the capital market as the risk premium [6], as the return on a company's assets [7], and human capital computations [8-11]. The constant plays a significant role in different economic estimations and in establishing discount rates as well. 
The constant also plays a significant role in formulating the model of employee capital measurement and the derived models of consistent compensations. The basic relation established is $\mathrm{L}=\mathrm{p} \times \mathrm{H}(\mathrm{p})$, where $\mathrm{L}$ - denotes basic constant pay of an employee, and $\mathrm{H}(\mathrm{p})$ - denotes human capital of the employee.

Since a non-material artifact may be seen as money, a new equation of exchange ought to be introduced. It is each individual experience that we earn money as work receivables doing labor as employees and that we then exchange our work receivables for products. The modern equation of exchange depicts this undeniable fact. The introduction of the new equation comes before critics of the theory of money and the monetary equation of exchange.

\section{The Equation of Exchange-The Heart of Monetarism}

Discerning money as coins or other material artifacts yields the well-known equation of exchange. Accepting the relationship between the output of an economy and the number of coins $(N)$ in the hands of economic agents, one can write the equation GDP $=N \times V$, where $V$ denotes velocity of circulation. Then, introducing the variable of inflation, the equation is as follows:

$$
\mathrm{GDP}=\mathrm{GDPR} \times(1+i)=N \times V,
$$

where GDPR denotes real GDP (current GDP valued in past-year prices), and $i$ denotes inflation. The main conclusion stemming from the above equation is well known; the level of inflation is closely related to the number of coins. The reshaped equation is $1+i=N \times V / G D P R$. Since coins are now replaced by cash money (banknotes produced from paper and lent to commercial banks or chosen financial institutions under the supervision of the central bank), the $N$ is replaced by the amount of money $M$. Of course, there are some complications in measuring $M$, hence we experience a sequence of $M, M 1, M 2, \ldots$.

Thus, the well-known monetarist equation of exchange is as follows:

$$
\text { GDP }=\text { GDPR } \times(1+\mathrm{i})=M \times V
$$

Here $M$ is the amount of money circulating with velocity $V$. Here appears a fundamental difference between the coins equation GDP $=\operatorname{GDPR} \times(1+i)=N \times V$, and the equation GDP $=\operatorname{GDPR} \times(1+i)=M \times V$ with the variable $M$. The first equation is subdued by limitations of reality. Nobody can produce coins from nothing, by fiat. Instead, the second equation with variable $M$ is the theory, which admits that money is created by fiat. This is a fundamental error against the natural laws of reality, which charges fatal monetarism and economies.

Using such eerie concepts as basic amount of money, we may decrease inflation, but only by destroying the economy. Thus, the language used by monetarists is filled with expressions like overheated economy (we need and should cool it down), shock therapy, restrictive monetary policy, and so forth. Followers of quantitative "theories" of money possess an ample arsenal of means and numerous "merits" in "cooling the economy down"; in other words, causing unemployment and decreasing the standard of living.

The bad effects of monetarism for an economy are much greater. Monetarism is the reason for budget deficits, taxation of fair pays, and unemployment. It changed our friendly world from a natural eight percent potential for growth [12] to a kind of economic imprisonment. In a normal world, without false monetarism, labor is the source of money. The more productive the labor is, the more money there will be in the hands of citizens. Instead, we are in a world governed by the rule of "we cannot do it since we do not have money." The most important drawback to economic theory concerning money is extremely serious. The present theory of money is not a kind of science because it admits that the ability of doing work (capital, energy) is created ex nihilo. The law of energy conservation has been commonly accepted as fundamental law [5] since the second part of the 18th century, and the creation of capital is unfeasible. The central banks are not able to break this fundamental law either. But its action creates chaos in all economic matters. The correct view is the only one. Money arises as evidence of work done; as work receivables.

\section{The Triad: Capital-Labor-Money}

Accomplishing labor creates two economic categories: products (where capital transferred by labor is concentrated) and work receivables, which is the accounting record of the value of work done, as illustrated in Figure 1. The last category is our money, and it is exchanged for goods. Money is the essence of the money-goods economy, which can be capitalistic or socialistic, free market or not. The right opposition to money - the goods economy-is a barter economy. The latter also involves an economy with coined money, that is to say some material artifacts as the "means of payment."

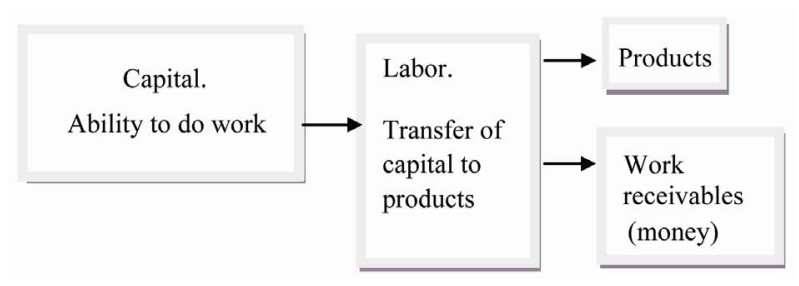

Figure 1. The triad: Capital—labor-Money. 
When an employee transfers his/her human capital to a product in the process of labor, the transfer related to the work compensation (which should be fair) is also determined. Then money appears as a category of a wage receivable and consequently, with the duality principle, as a payable. Therefore, in line with the duality principle, the employer has adequate liability (payable). Let us note that the category of receivables requires a measurement of value with an abstract account unit. This is possible since all these categories: capital, labor, work receivables, and payables are measured by the same abstract unit of measurement. It is a money unit and a labor unit as well.

Plenty of research exists where authors are skeptical about a positive meaning of the present theory and practice of money. R. W. Garrison [13], who represents the contemporary Austrian School of Economics, expresses a moderate opinion that:

"...Unavoidably, the medium of exchange is also a medium through which difficulties in any sector of the economy - or difficulties with money itself-get transmitted to all other sectors. Further, the provision of money even in the most decentralized economies is - not to say must be - the business of the central authority. ... Money comes into play both as a source of difficulties and as a vehicle for transmitting those difficulties throughout the economy."

The present state of knowledge concerning monetary unit is clearly expressed by A. V. Banerjee and E. S. Maskin [14], who wrote:

"...Money has always been something of an embarrassment to economic theory. Everyone agrees that it is important; indeed, much of macroeconomic policy discussion makes no sense without reference to money. Yet, for the most part, theory fails to provide a good account for it. Indeed in the best-developed model of a competetive economy the Arrow-Debreu framework-there is no role for money at all. Rather than there being a medium of exchange, prices are quoted in terms of a fictitious unit of account, agent(s?) trade at those prices, and that is the end of the story..."

The present state of the art concerning money is comprehensively described by T. G. Buchholtz [15]. In the chapter X, where the author discusses Milton Friedman and the monetarist battle against J. M. Keynes, one can find a paragraph arriving at the essence of money as follows: "What is money? Anything can be money, including shells and beads; cigarettes often serve as money in prison. In today's macroeconomic lingo, we follow the Federal Reserve Board definition of money supply. The most popular measure is called $M 1$..." How does someone know that money is material and that we expect a supply of money? The author continues: "Why would anyone be foolish enough to argue about the money supply? Wrong. ... If the amount of money over- whelms the capacity to produce goods, consumers, with more money to spend, bid up prices."

Figure 1 shows that money is the final part of the triad: capital-labor-money. Money arises as an abstract category of wage receivables that come into existence after accomplishing work and making adequate accounting entries. Money is immaterial. Human labor is naturally measured according to the unit of labor so it is a money unit as well. This is common knowledge for all employees who work and feel every working hour, who often feel tired transferring their energy (human capital) through labor, and who sometimes do not get an equivalent exchange for these transfers.

This point of view allows us to overcome old habits resulting from seeing the monetary system as based on metal or bimetal or even as paper money. The creation of money by the central banks for use by commercial banks is a fact, but not a natural one. It is beyond the scientific approach since it violates the conservation principle. From one side, the employee's work and earnings represent an equivalent of labor (transferred human capital), and from the second side an institution creates money by fiat.

Recently a group of thinkers (B. Lietaer [16], D. Rushkoff [17], and others) raised the problems with the present money system to propagate the concept of an open source currency. D. Rushkoff explains “...Open Source or, in more common parlance, "complementary" currencies are collaboratively established units representing hours of labor that can be traded for goods or services in lieu of centralized currency. ... So instead of having to involve the Fed in every transaction-and using money that requires being paid back with interestwe can invent our own currencies and create value with our labor..."

Open-source currency is a progressive concept that correctly conceives money as tightly related to labor. It is, however, not satisfactory since we do not need complementary money to make our tough existence easier. We need, rather, ultimate knowledge about the essence of the money-goods economy. What is money in particular? The answer is clear. Our money is our work receivable. Our money arises as confirmation of work done and it represents the value of labor transferred by laborers. The real transfer of human capital into products occurs only in the labor process. Therefore we say that labor is always self-financing.

Adam Smith [18] wrote that "...What is bought with money or with goods is purchased by labor as much as what we acquire by the toil of our own body. That money or those goods indeed save us this toil. They contain the value of a certain quantity of labor which we ex- 
change for what is supposed at the time to contain the value of an equal quantity. Labor was the first price, the original purchase-money that was paid for all things. It was not by gold or by silver, but by labor, that all the wealth of the world was originally purchased; and its value, to those who possess it, and who want to exchange it for some new production, is precisely equal to the quantity of labor which it can enable them to purchase or command...". 1

Regrettably, these right words have not changed economies to a natural state, where labor produces money so that labor is self-financing. The phenomenon of selffinancing is extremely advantageous for economies. It means that governments need not raise money to fund the public sector's payroll. Instead of collecting funds through taxation, an authorized government agency (the reformed central bank) ought to make appropriate transfer entries in the commercial bank account of the employees. The only constraint is the size of the public sector, as the paper explains [12].

The self-financing of labor means that labor is an exclusive process that may produce money as evidence of labor performed and represented by the laborer's receivable. In the case of a company, its products need market approval; in other words, the company needs to make a sale. In the case of public sector units, their activities do not need market approval. Instead, these activities are subject to a set of standards and procedures, like those required of public school teachers. To be a teacher, an individual has to accumulate his/her human capital to determine an adequate ability to perform labor-in this case, the tasks of a teacher. While teaching, he/she transfers his/her human capital to the pupils, who gain value as future workers in society.

The fundamental inaccuracy of current economic theory is concentrated in the central bank's activity. This is not the fault of some central bank officers. The line of thinking that the economy needs institutions to create money, and the suggestion that money can be something material is absolutely damaging. Therefore, economies operate on the basis of, "we can do nothing since we have no money." As an alternative, economies should operate according to the statement "we can do it since we have qualified employees and adequate knowledge." This is the road to the peaceful welfare of the state and the world. Sciences and techniques provide a firm basis for this and similar opinions.

The central bank operating in the present theoretical environment blocks natural productive resources existing in the economy. The central bank's production of money creates the following obstacles:

${ }^{1}$ A. Smith, An Inquiry into the Nature and Causes of the Wealth of Nations. Edwin Cannan, ed. 1904. Library of Economics and Liberty, Retrieved June 23, 2010.
- It violates the fundamental principle of energy conservation, therefore economics does not adhere to scientific rules;

- It blocks many advantages resulting from the selffinancing of labor;

- It forces governments to raise taxes;

- It reduces demand;

- It causes inflation and economic crises; and

- It causes unemployment.

Therefore, current money creating procedures lead to financial instability. This is why stock market valuation can grow at a much higher rate for many years than the natural average rate of growth determined by the constant $\mathrm{p}=8 \%$. Consequently, sooner or later, an adjustment to the long-term rate of return is unavoidable. There are more drawbacks resulting from the present state of money affairs. However, the ones just pointed out suffice as a premise for the principal reform of the central bank's role. It is crucial for economic stability.

Activists of the American Money Institute refer to a speech made by Congressman Wright Patman ${ }^{2}$, Chairman of the House Committee on Banking and Currency for over 16 years [19], who said significantly:

"I have never yet had anyone who could, through the use of logic and reason, justify the Federal Government borrowing the use of its own money...I believe the time will come when people will demand that this be changed. I believe the time will come in this country when they will actually blame you and I and everyone else connected with the Congress for sitting idly by and permitting such an idiotic system to continue."

The defect in understanding money leads to growing budget deficits and an expanding public sector. But the public sector cannot be financed entirely by growing taxes. People in a democratic country will not agree to pay for misunderstandings of the economists and politicians. What's more, they cannot afford to pay ever greater taxes. Therefore, economies become what D. Rushkoff called scarcity engines [17]. The more developed the economy, the greater the deficit, as is the case in well-developed states like Germany and France. Of course, budget deficit can be an issue of incorrect management, but we have considered well-governed countries.

\section{The Wage Equation of Exchange and Control of Money Stability}

The most important way of controlling inflation is by not allowing a decline in the labor productivity ratio $Q$ determined as the quotient of real GDP (GDPR) to total

${ }^{2}$ Retrieved June 23, 2010 from the World Wide Web of the American Monetary Institute.

http://www.monetary.org/need_for_monetary_reform.html 
compensation $W$ of employees. If $Q=\mathrm{GDPR} / W$ is con stant or, better yet, is growing, then inflation is under control. Moreover, inflation can grow if 1) the public sector is too big compared to the private sector, or 2) credits taken from commercial banks exceed adequate limitations. Therefore, policy makers can simultaneously apply two tools. The first is determining the upper limit of credit; the second is determining the size of the public sector that cannot exceed the sum of compensation determined by the labor productivity ratio $Q$. To determine the adequate amount of credit, we introduce the wage equation of exchange.

Having understood economy as a constant flow of capital, we reach the most essential Figure describing the dual nature of the money-goods economy. The essence of the money-goods economy is the existence of two streams: the stream of products and the stream of money. The source of those two streams is labor of human capital; but the stream of products arises as a result of a composition of labor costs and assets of various kinds, while the other stream consists of receivables and partly credit money. This stream is created by a sequence of accounting entries recorded and transferred into the banking system. A constant confrontation between the products and the stream of money takes place in the market; as a consequence of this confrontation, the value of exchange is determined. This exchange leads to the equation of exchange of money for goods and vice versa (Figure 2).

In the process of exchanging goods and money, basic economic values are shaped that characterize the economy; in particular, the Gross Domestic Product, labor productivity $Q$, and the inflation index. Measurement of these values is based on the performance principle; therefore, it is done according to market value. When we look at it from an accounting perspective, we can talk about the dynamic balance of the goods and money economy, in which the above variables are revealed as a result of a given market configuration and the goodsmoney exchange. The exchange process is illustrated by Figure 2, which in turn enables the formulation of an exchange equation.

The bottom of Figure 2 shows that it is human beings who set in motion the labor process. We consider not an individual but human capital denoted by letter $H$, which can be precisely measured in economic terms, and the percentage $(u)$ of human capital $H$ determines market pay $(W=u \times H)$.

The left side of the Figure shows the process of producing goods and services. Labor costs $(W)$ composed with various sorts of assets make final products $(P)$ measured in historical costs before confronting with money claims of payable holders (please check). The relevance of the amount of labor used in a particular instance to the market accepted amount is tested in the marketplace. The process of production is modeled by the natural (not econometric) production function, which can also serve as a determinant of wage productivity $Q$. Therefore GDPR can be introduced as product GDPR = $W \times Q$, and, as shown by M. Dobija [20], we can use the formulas:

$$
Q=\mathrm{GDPR} / W=\exp [A F / H]=\exp [A F p / L]=\exp [T F]
$$

where: $A$-end-of-period value of assets, $H$-human capital, $L$ - constant basic pay $(L=p \times H), p$ - the constant of potential growth (0.08), $T$-technical equipment of work, $F$-level of management.

The right side of Figure 2 shows not material streams but a stream of records arising as a result of pay receivables considered from the employees' point of view or pay liabilities considered from the State's point of view. The State and the banking system are responsible for a smooth exchange of money for products that match the expectations of money holders. The banking system's role is also the creation of credit money (parameter $\mathrm{k}$ ) in a way that is adequate for the economic requirements. We shall see later that that process should depend exclusively on real wage productivity. It depends to some extent on parameter (a), which reflects society's attitudes and degree of poverty (or wealth).

The upper box shows the constantly accomplished exchanges: money for products and vice versa. This is the essence of the monetary economy - that the records of wage receivables are exchanged for goods. Despite the fact that these receivables change owners and play the role of the most desired assets, they still remain as liabilities of the state system. This process can be roughly described by the equation of exchange. Obviously, more money in respect of the bulk of goods and higher prices would lead to higher inflation. However, pay should be in accord with the value of labor. This is the only correct conclusion stemming from the above considerations.

The wage equation of exchange arises by natural algebraic depiction of Figure 2. Assuming that market mechanism does equalize the value of streams of money and products, the following equation can be written and called 'the wage equation':

$$
\begin{aligned}
\mathrm{GDP} & =\mathrm{GDPR} \times(1+i)=W \times Q=M_{K} \\
& =a \times W+(1-a) W /(1-k)=W \times K(a, k),
\end{aligned}
$$

where GDPR - denotes real GDP, and $i$-denotes inflation.

The following condition stems directly from the above equation of exchange:

$$
W \times Q r \times(1+i)=W \times K(a, k),
$$

where $Q r$ denotes real work productivity $(Q r=Q /(1+i))$. Hence we obtain condition; if $i=0$, then $K(a, k)=Q r$, 


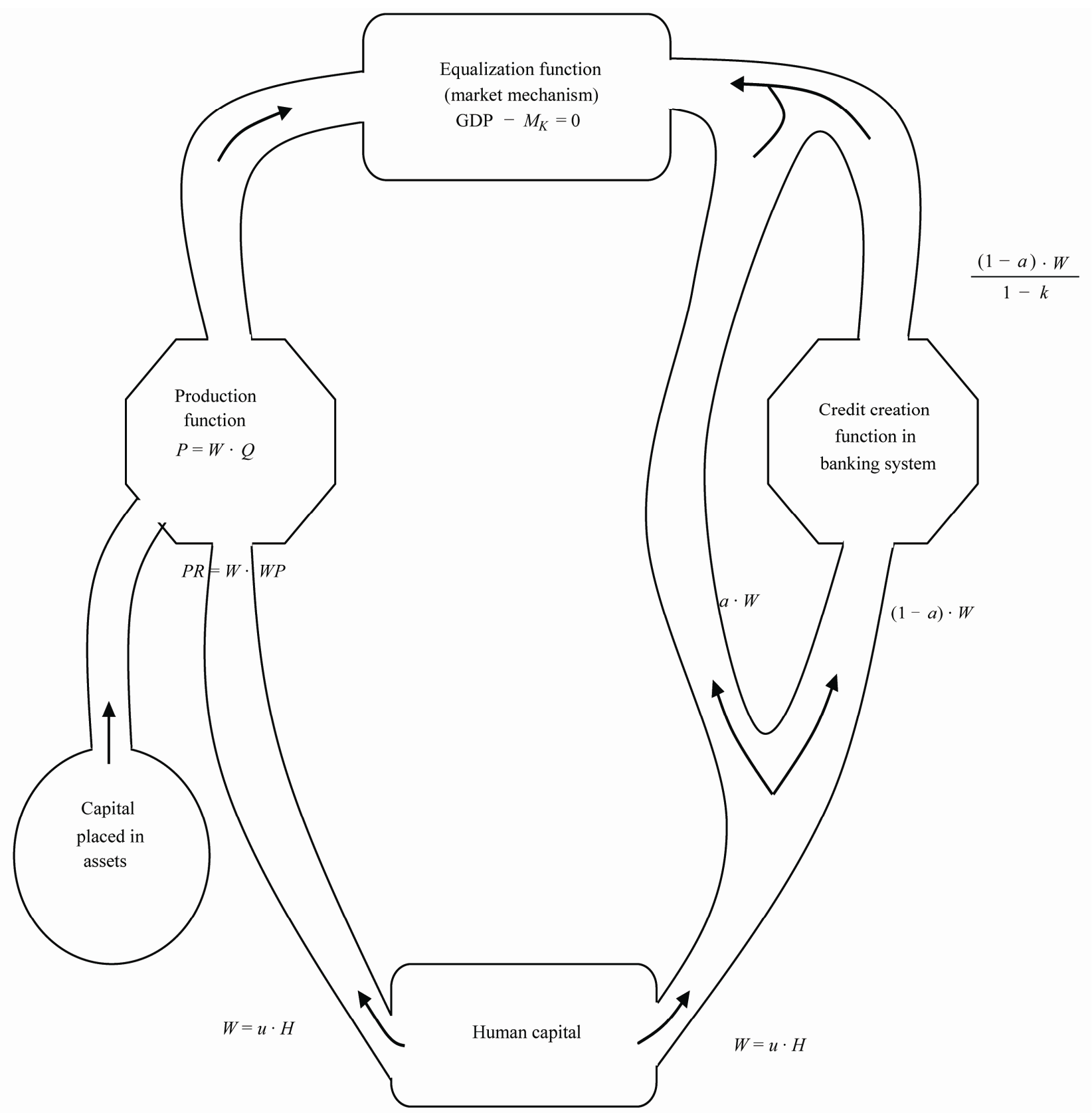

Figure 2. The market mechanism equalizes the stream of products and the stream of money. Source: M. Dobija, "Wage, Money and Accounting: Theoretical Relationships," Argumenta Oeconomica Cracoviensia, No. 2, 2003, pp. $27-50$.

so that real labor productivity determines variable $K(a, k)$, and the possible size of credit.

The money stream can also be quantified as the function of wages $(W)$. Wages paid to employees split into two lesser streams. The first stream has measure $a \times W$, $(0<a<1)$, and tends to be directly on the market without a banking system. The money stream can also be quantified as the function of wages $(W)$. Wages paid to employees split into two lesser streams. The first stream has measure $a \times W,(0<a<1)$, and tends to be directly on the market without a banking system. This means that the exchanges are done immediately. Parameter (a) arrives at this part of wages that is exchanged for products directly, without becoming a bank deposit that can be used for credit action. The parameter can be interpreted as welfare or poverty level and saving propensity. The second part of the original stream of wages $(1-a) \times W$ firstly feeds the banking system and enables it for credit action. Then it is amplified in the banking system (credit money creation) and flies into the market linking earlier 
with the first sub-stream. Some part of this stream (which is not disclosed on the Figure) is not used by the banking system as a basis for credit creation because of the mandatory reserves system and the requirements of current accounts conditions. We omit reserves in the present considerations so that the formula is as follows:

$$
M_{K}=a \times W+\frac{(1-a) \times W}{1-k}
$$

where $k$ denotes a parameter of the credit money creation. The total stream of money is therefore equal to:

$$
M_{K}=W \times K=W \frac{a \times(1-k)+(1-a)}{1-k}
$$

The problem of determining a right value of credit money creation parameter $k$ (that minimizes the level of inflation) can be solved by using a fragment of the equation of exchange as follows:

$$
\operatorname{GDPR} \times(1+i)=W \times K
$$

Solving for variable (i) we obtain formula:

$$
i=\frac{K}{Q_{r}}-1
$$

where $Q r=\mathrm{GDPR} / W$ is real wage productivity.

Assuming a condition $i=0-K=Q r$ we can find the value of the parameter $k$ that minimizes the inflation level. Using the equation:

$$
a+\frac{(1-a)}{1-k}=Q_{r}
$$

We obtain the equation:

$$
1-k=\frac{(1-a)}{Q_{r}-a}
$$

Thus the wage multiplier (Figure 2) is equal to:

$$
\frac{1-a}{1-k}=\frac{\left(Q_{r}-a\right)(1-a)}{(1-a)}=\left(Q_{r}-a\right)
$$

The ultimate opinion is that the stream going through the banking system can be increased to a level $\mathrm{W}\left(Q_{r}-a\right)$ or in the rearranged form to $\operatorname{GDPR}\left(1-a / Q_{r}\right)$. The size of the credit depends on the wage level $(W)$, welfare level (a), and the productivity level as well.

To keep control over the money supply should only mean adequate compensation systems as well as a precise feasibility study with respect to investment projects that involve debt financing in particular. Constant pays should be determined on the basis of employees' human capital as discussed by M. Dobija [8,9], and I. Cieślak and M. Dobija [10]. As is proved, constant pay equal to the established human capital in line with formula $L=p$ $\times H$, guarantees that employees' human capital is pre- served. A level less than $p=8 \%$ would lead to its depreciation. Further research by W. Kozioł [12] has shown that total compensation, which also includes premium pays and fringe benefits, attains a level exceeding $10 \%$ of employees' human capital.

\section{Elimination of the Budget Deficit of a Well-Governed Country}

In the case of the private sector, employers have to cover the costs of labor and other costs by sales inflows. On the other hand, in the case of the public sector, the employer (the state) does not need to have inflows in order to pay for labor. State officers have to confirm contributed labor and appropriate entries that transfer money to commercial bank accounts. Labor done is the real transfer of workers' capital, and salaries paid in money are merely affirmation of this fact. Therefore, as stated by M. Dobija [21], "The government can spend money, which it does not own and does not need to give it back, under the condition that is able to see that labor finances itself and money arises as the result of work." The current state of affairs is far from the correct approach presented here. Government organizes a tax system to pay for labor in the public sector, which is what hurts the economy by diminishing demand and causing a budget deficit.

If a public school teacher (productivity coefficient 3/4) taught pupils for a month (180 hours), he/she would obtain an entry confirming his/her receivables for an amount of 135 currency unit. There is no question where the money would come from for the teacher's salary; there is no need to collect tax to pay for the teacher's work. Government, as a supervisor of the public sector, is authorized to issue adequate compensation. Such an approach opens up the possibility of reshaping the economy to a much more prosperous state than is possible under the current system. A canon of the future economy is self-financing of labor and avoiding the taxation of fair pay; this means the pay that is consistent with the human capital of the employees. Under the new proposed system, one can expect a better relationship between supply and demand, a more correct market valuation, and, of course, the disappearance of the budget deficit.

The economy can be balanced and it can get rid of the budget deficit upon implementation of the fundamental changes in conceiving and controlling the monetary system and the way the public sector is financed. The presented ideas lead to principal reform of the central bank. The main new function of this institution is to make payments for labor performed and accounted for in the public sector. It is the only correct process of money creation since economy is a collection of capital flows that are set in motion by natural forces and labor. 
How the proposed reform could improve an economy is illustrated by the computations in Table 1 . The case concerns the Polish economy in 2010. The ratio of the cost of labor in the private and public sectors is estimated $^{3}$ at 8:2. The $Q$ is estimated on the basis of Table 2.

Poland, like many other countries, suffers from a lack of funds for public works, despite urgent needs and ca $13 \%$ unemployment. Most salaries and wages are low so the politicians cannot raise more taxes. There are other problems hindering progress. Children outside towns walk to their schools on roads used by heavy trucks. The recent great flood caused an estimated loss of ca 12 billion PLN. This loss would have been smaller if the country had been better prepared. A large part of the Polish workforce is employed abroad (ca two million) and a lot of young people plan to go abroad in search of work. The injection of the European Union's subsidies has helped to improve the economic conditions somewhat.

The proposed reforms illustrated in Table 1 would allow Poland to undertake the required public works valued

Table 1. The proposed reforms.

\begin{tabular}{|c|c|c|c|}
\hline & Description of variable & Present system & $\begin{array}{l}\text { Reformed } \\
\text { system }\end{array}$ \\
\hline 1 & $\begin{array}{l}\text { Labor productivity ratio } \\
\text { (optimistic) }\end{array}$ & 2.0 & 2.0 \\
\hline 2 & $\begin{array}{l}\text { Estimated real GDP } \\
\text { (optimistic) }\end{array}$ & 1300 billion $^{*}$ & 1300 billion \\
\hline 3 & Estimated compensations & 650.0 billion & 650.0 billion \\
\hline 4 & $\begin{array}{l}\text { Compensation in the } \\
\text { private sector }\end{array}$ & 520.0 billion $^{*}$ & 520.0 billion \\
\hline 5 & $\begin{array}{l}\text { Compensation in the public } \\
\text { sector }(20 \%)\end{array}$ & 130.0 billion & 130.0 billion \\
\hline 6 & Budget deficit (planned) & 52.2 billion & - \\
\hline 7 & Inflow from pay taxation & 36.0 billion & - \\
\hline 8 & $\begin{array}{l}\text { Offsetting the budget } \\
\text { deficit and the pay tax by } \\
\text { self-financing of labor }\end{array}$ & - & 88.2 billion \\
\hline 9 & $\begin{array}{l}\text { Funds for public works } \\
(130.0-88.2)\end{array}$ & - & 41.8 billion \\
\hline $10^{\dagger}$ & $\begin{array}{l}\text { Limit of credit: } W \times \\
(Q 2009-a), a=0.85 \\
\text { (rough estimation) }\end{array}$ & $\begin{array}{l}\text { Actual value } \\
\text { was } 612.0 \text { bil- } \\
\text { lion in } 2009\end{array}$ & 682.5 billion \\
\hline $11^{\dagger}$ & $\begin{array}{l}\text { Inflow of central bank } \\
\text { income }\end{array}$ & ca 5.0 billion & 0.0 billion \\
\hline $12^{\dagger}$ & Interest on public debt & ca 32.0 billion & \\
\hline $13^{\dagger}$ & $\begin{array}{l}\text { Subsidies from European } \\
\text { Union }\end{array}$ & ca 32.0 billion & ca 32.0 billion \\
\hline
\end{tabular}

*Name of currency unit is PLN, ${ }^{\dagger}$ Additional information

${ }^{3}$ The ratio was verified with Department of Finance Policy, Analysis and Statistics of the Ministry of Finance, Poland. at 16.2 billion PLN (21.2 - 5.0). Then unemployment would go down and demand would be higher. Public debt would start to diminish, along with the high level of interest now paid, which is an enormous burden to the Polish economy. The country would find a path to balanced development.

It is common knowledge that taxation is unavoidable. But the truth is it is the labor and natural forces, not taxes, that originate wealth. A tax less economy is conceivable in the light of labor self-financing. The first step in reshaping the present economy should be to apply the labor self-financing principle to the public sector. This would open the source of financing for assets and other aims. Then, the second step would rely on adjusting the existing tax system towards significantly decreasing or even cancelling direct payroll taxes. This is an important step since taxation of income makes employees poorer and decreases the purchasing power available in the economy. This, in turn, badly affects entrepreneurship.

In the light of labor self-financing, the needs for funds from taxation are genuinely limited. Tax funds are required for some other aims, excluding compensations, in the public sector such as:

- Financing of construction and acquisition of assets being obligatory in the public sector;

- Financing of the maintenance of assets in the public sector;

- Financing of subsidies for mothers raising children;

- Financing medical care for children;

- Financing the social safety net and care;

- Financing foreign military and other foreign operations.

Subsidies for mothers raising children can be justified by the fact that they are directly forming new human capital by performing tiring labor. It is beyond discussion that the effort should be recognized and rewarded. Mothers and children need a source of existence. In addition,

Table 2. The estimated ratios $Q$ for $2006-2009$.

\begin{tabular}{lllll}
\hline Country & 2006 & 2007 & 2008 & 2009 \\
\hline USA & 3.458 & 3.470 & 3.560 & 3.500 \\
Japan & 3.069 & 3.093 & 3.186 & 3.433 \\
UK & 3.204 & 3.517 & 3.444 & 3.082 \\
Switzerland & 3.534 & 3.645 & 3.748 & 3.650 \\
Switzerland & 3.290 & 3.380 & 3.389 & 3.276 \\
Czech & 1.873 & 2.204 & 2.355 & 2.210 \\
Republic & 1.881 & 1.992 & 1.854 & 1.869 \\
Poland & 1.415 & 1.512 & 1.685 & 1.762 \\
China & & & & \\
\hline
\end{tabular}

Source: Own estimation following the paper [20]. 
mothers should compound some money for their pension funds. The remuneration of mothers is one of the factors that determine how developed a country is. This problem is complex but it can be solved through the self-financing phenomenon. However, in the beginning, a safe solution is to finance this labor from tax funds. The pay should be consistent with the theory of human capital. This means it should be close to a minimal legal wage.

It is common knowledge that labor in the public sector is less efficient than it is in the private sector. This is, however, not a law or a principle. Efficiency depends much on the self-awareness of the officers and supervisors, and generally depends on the quality of the institutional capital. The State may legislate that health care for children and youth belongs to the public sector. The division between the public and private sectors can vary over time, influenced by models accepted by policy makers. Government can choose the less efficient variant, preferring to fulfill some of the social aims. For instance, prisoners while less productive, should have an opportunity to work because that helps them to rehabilitate and readjust to society's standards.

\section{Indispensable Reform of the Central Bank}

The entire financial system of the state could change significantly for the better through the application of labor self-financing, provided that the principal role and functions of the central bank would change. Adjusting the monetary system to the fundamental principles of reality requires principal changes to the procedures of "money creation." To think of "money creation" is generally incorrect since nobody can create money representing value as nobody, in reality, can originate energy as far as we know. Therefore, the one important point of the reforms is to extinguish cash money. The cash money should be a relic of the period when money was not related to labor because money was not perceived as the legal receivable of work done. Cash money could be used for a transitional period as a form of work receivable, which an employee keeps on hand instead of keeping it in the bank account. In any case, in the first step, the central bank would have to stop issuing any new cash money.

Figure 3 shows the structure of the reshaped financial system.

The road to a deficit-less economy leads through the essential reforms of the central bank. After transformation this institution would become a positive and indispensable one. The reformed economy requires fulfilling two additional functions. The first is to control productivity both in the private and public sectors - de facto control over inflation and over stability of the exchange rate to some extent. The second responsibility of the central

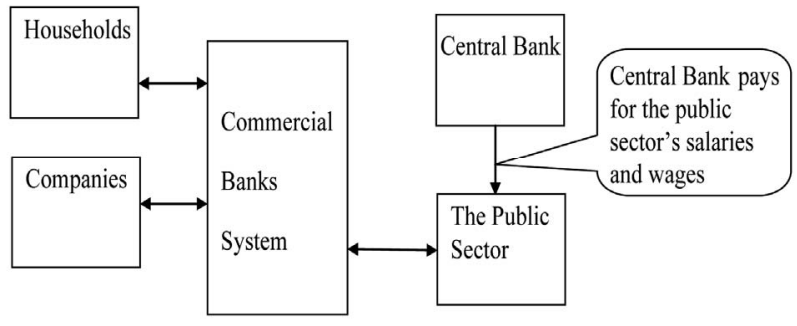

Figure 3. The reshaped financial system.

bank is entirely new; it is to pay for the wages and salaries of the employees in the public sector. The central bank would be the only institution authorised to transfer wages and salaries to these employees' accounts held in commercial banks. An additional function related to the two mentioned above is the control of remuneration in the public sector and its consistency with the valuation of human capital.

The main changes of public finances, including central bank reform, are listed as follows:

- Removal of the cash money and definitely putting an end to its existence. Bank deposits, credits related to deposits, bank accounts, and cards facilitating access to the accounts are the most essential parts of the new money system;

- Essential change of the role of the central bank into a government agency responsible for controlling labor's productivity in the economy. The agency is responsible for payroll services for the public sector, namely, payment of employees' earnings to their accounts in the commercial banks;

- The central bank no longer creates fiat money for commercial banks. This government's institution is not a bank, but an agency authorized to control the adequacy of commercial banks' equity capital and reserves and compliance with liquidity standards. It neither purchases nor sells securities. It does not earn income. This is the only institution authorized to transfer the public sector pays to accounts in commercial banks. Its independence concerns only evaluation of the labor productivity ratio;

- Commercial banks operate under the supervision of the reformed central bank or other government agencies that control the assumed capital adequacy and highly standardized level of liquidity;

- The achieved and planned level of labor productivity is the principal budgetary constraint;

- The sum of salaries that can be paid out in a period in the public sector is determined as a function of labor productivity $Q$;

- Interest rates and exchange rates are exclusively shaped by free market exchanges;

- Growing labor productivity in the economy is the 
only source of increasing salaries in the private and public sectors;

- Control of inflation means maintaining pay consistency with the value of labor and not permitting a decrease of ratio $Q$. This ratio ought to have a growing tendency;

- A fair basic pay is consistent with the value of employees' human capital. In addition, compensation involves a premium pay and other fringe benefits having their source in companies' income;

- Taxation of basic fair pay is removed. Taxation would make it unfair.

The key benefits of these changes come from the fact that the government doesn't need to raise funds from taxation in order to pay for public sector employees. The ability to pay fair compensation is no more limited by collected tax. Then one can expect a more efficient market, less unemployment, and a balanced economy.

\section{Obligatory Liberating of Fair Compensation from Tax Charge}

A deficit-less economy should also assure fair compensation for all employees. Minimal constant pay $(L=0.08$ $\times \mathrm{H}$ ) does not allow for depreciation of employee's human capital. This means that a couple has the required resources needed for the cost of living of a four-person family, and children can obtain a parent's level of professional education. Therefore, we have to assure that taxes will not change fair constant pay to unfair pay. The phenomenon of labor self-financing helps to find the right solution.

The problem of liberating compensation consistent with employee's human capital can be solved by different modes. However, in order to maintain simplicity and integrity of taxation, a good idea is to use a high tax-free threshold. Namely, pay below the threshold is tax free. Income over the threshold and less than maximum fair pay is taxed at a low rate. The income over fair pay defined by human capital valuation is taxed at a higher progressive rate.

- Pays less or equal to average pay (threshold) — tax free;

- Pays greater than threshold pay-insubstantial taxation with constant rate. The basis for taxation is the difference between pay and threshold pay;

- Pays greater than maximum fair pay but less than the upper limit-taxation with growing rate. The basis for taxation is the difference between maximum fair pay and threshold and pay and maximum fair pay;

- Pays greater than the upper limit - taxed at a high steady rate.
Illustration. An employee who earns $€ 10000$ per month would be charged $6.6 \%$ tax. This amount is computed as follows. Assumptions: $€ 4000$ - tax-free threshold, $€ 7000$ - maximum fair constant pay. Tax rates are respectively $10 \%$ and $12 \%$.

- Zero percent of $€ 4000=€ 0$.

- $\quad$ Ten percent of $(€ 7000-€ 4000)=€ 300$

- Twelve percent of $(€ 10000-€ 7000)=€ 360$

- Total tax €660.

- $\quad$ Effective tax rate $=660 / 10000=0.066(6.6 \%)$.

With such a structure, an employee who earns $€ 6000$ monthly would pay $€ 200$ tax. Someone who earns $€ 4100$ would pay $€ 10$ tax, and so on.

The progressive tax rate is applied to income greater than the maximum fair pay established here on the level of $€ 7000$. It is assumed that each additional thousand of Euros has its own rate increased by a figure taken from an interval $(0.5 \%-1.0 \%)$. Assuming the maximum rate of growth as $1 \%$, the eighth thousand is taxed at $11 \%$, the ninth thousand is taxed at $12 \%$, and so on. Thus, in the considered example, the exact size of tax from the amount exceeding $€ 7000$ is computed as follows: $0.11 \times$ $1000+0.12 \times 1000+0.13 \times 1000=110+120+130=$ $€ 360$. Policymakers may establish the rate of growth at less than one.

The tax rate is stepped up to a certain level, and then it stays constant. If the upper limit is fixed at the level $€ 50$ 000 , pay over $€ 50000$ would be taxed at the rate of $53 \%$. The last rate concerns individuals with high creative capital. Movie stars, football stars, inventors, among oth- ers, earn top income thanks to the personal attributes perceived and accepted by others. They usually act in a well-developed environment cultivated by state and society, which is necessary for their actions. Therefore, it is fair to pay more tax as the society creates an adequate environment for their activities, and it is right to recognize that the creative capital of these persons should be fairly remunerated.

\section{Conclusion}

The constant perception of capital, labor, and money as abstract categories leads to entirely new views about economic matters. An essential part of new theories is the phenomenon of labor self-financing. It liberates an economy from a significant part of tax burdens and leads to a deficit-less economy as well. There is only one requirement. Namely, abolishing cash money and recognizing the indispensable fact that money arises by labor.

\section{References}

[1] J. C. Bliss, "Capital Theory and the Distribution of In- 
come," North-Holland Publishing, Oxford, 1975.

[2] H. De Soto, "The Mystery of Capital: Why Capitalism Triumphs in the West and Fails Everywhere Else," Basic Books, New York, 2000.

[3] P. Mirowski, "More Heat than Light, Economics as Social Physics: Physics as Nature's Economics," Cambridge University Press, Cambridge, 1989.

[4] M. Dobija, "Abstract Nature of Capital and Money," New Developments in Banking and Finance, Chapter 4, Nova Science Publishers, Inc., New York, 2007, pp. 89-114.

[5] P. Atkins, "Four Laws That Drive the Universe," Oxford University Press, Oxford, 2007.

[6] W. N. Goetzmann and R. G. Ibbotson "History and the Equity Risk Premium," 2005. http://ssrn.com/abstract=702341

[7] B. Kurek, "The Risk Premium Estimation on the Basis of Adjusted ROA," General Accounting Theory. Evolution and Design for Efficiency, Wydawnictwa Akademickie i Profesjonalne, Warsaw, 2008, pp. 375-392.

[8] M. Dobija, "How to Place Human Resources into the Balance Sheet," Journal of Human Resource Costing \& Accounting, Vol. 3, No 1, Spring 1998, pp. 83-92. doi:10.1108/eb029044

[9] M. Dobija, "Human Resources Costing and Accounting as a Determinant of Minimum Wage Theory," Zeszyty Naukowe UEK, No. 553, 2000, pp. 39-62.

[10] I. Cieślak and M. Dobija, "Teoretyczne podstawy rachunkowości kapitału ludzkiego (Theoretical Ground of the Human Capital Measurement)," Zeszyty Naukowe UEK, No. 735, 2007, pp. 5-24.

[11] W. Kozioł, "Pomiar kapitału ludzkiego jako podstawa kształtowania relacji płac w organizacji (Human Capital Measurement for Shaping the Pay Relationships)," Ph.D. Dissertation, Library of Cracow University of Economics, Kraków, 2010, pp. 191-195.
[12] M. Dobija, "Theoretical Grounds of Public Finance Reform," Argumenta Oeconomica Cracoviensia, No. 5, 2009, pp. 6-20.

[13] R. W. Garrison, "Time and Money. The Macroeconomics of Capital Structure," Routledge, London and New York, 2001.

[14] A. V. Banerjee and E. S. Maskin, "A Walrasian Theory of Money and Barter," Quarterly Journal of Economics, Vol. 111, No. 4, November 1996, pp. 955-1005. doi: $10.2307 / 2946705$

[15] T. Buchholz, "New Ideas from Dead Economists: An Introduction to Modern Economic Thought," A Plume Book, New York, 2007, pp. 229-234.

[16] B. Lietaer, "Complementary Currencies in Japan Today: History, Originality and Relevance," International Journal of Community Currency Research, Vol. 8, 2004, pp. $1-23$.

[17] D. Rushkoff, "Open Source Currency," What Is Your Dangerous Idea, Edge Foundation, Inc., Polish Edition, 2008.

[18] A. Smith, "An Inquiry into the Nature and Causes of the Wealth of Nations," Library of Economics and Liberty, 23June, 2010.

[19] The World Wide Web of the American Monetary Institute, 23 June 2010.

http://www.monetary.org/need_for_monetary_reform.ht $\mathrm{ml}$

[20] M. Dobija, "Labour Productivity Ratio and International Comparison of Economic Performance-Formalization of the PPP Theory and Preliminary Examinations," IEA 15th World Congress, Istanbul, 25-29 June 2008.

[21] M. Dobija, "Financing Labour in the Public Sector without Tax Funds," Argumenta Oeconomica Cracoviensia, No. 4, 2005, pp. 5-20. 